\title{
COMMITTEES OF BOARDS: AN EVENT STUDY ON AN EMERGING MARKET
}

\section{DOI: 10.17261/Pressacademia.2015211615}

\author{
Emrah ARIOGLU' ${ }^{1}$, Koray TUAN ${ }^{1}$ \\ ${ }^{1}$ Cukurova University
}

\author{
Keywords: \\ Committees of Boards, \\ Corporate Governance, \\ Borsa Istanbul, \\ Event Study
}

\begin{abstract}
This study investigates the market reaction surrounding the establishments of committees of boards, and director appointments to these committees based on the underlying reason for the appointments in public firms quoted at the Borsa Istanbul. In addition, it investigates how the market reaction changes based on the professional expertise of these directors. The findings suggest that investors in Turkish capital markets do not value the existence of various committees of boards highly. In addition, they do not appear to react differently to director appointments to these committees based on the underlying reasons for the appointments. Lastly, they do not seem to value the professional expertise of directors serving on these committees, except in the case of audit committees. Investor reaction surrounding the appointments of expert directors to audit committees is significantly higher compared to the appointments of non-expert directors to audit committees.
\end{abstract}

\section{INTRODUCTION}

A potential way of improving the effectiveness of monitoring provided by members of boards of directors is establishing committees. These committees could be useful corporate governance mechanisms in the protection of minority shareholders' benefits, as well as in the early determination of potential risks that companies might be subject to in future periods. Therefore, the establishment of these committees could lead to improved corporate governance quality and consequently increased firm value. However, effective functioning of these committees is as important as establishing them, in order to ensure that firms do not only "appear" to have improved corporate governance but actually carry out improved corporate governance practices. A factor that could be an important determinant of committee functioning effectiveness is the characteristics of members of these committees such as their professional expertise. The regulations in some developed countries that require companies to appoint at least one director with financial/accounting expertise to audit committees support this argument. 
Studies such as Sevim and Eliuz (2007), Nuhoglu and Armagan (2013), Kandemir and Akbulut (2013) investigate board committees in Turkish public firms with a special focus on audit committees. However, in this study we investigate various committees of boards from a different perspective: from the point of view of investors. We investigate how markets react to the establishments of committees of boards and director appointments to these committees in public firms quoted at the Borsa Istanbul (BIST). In addition, we investigate how the market reaction to committee member appointments and departures changes based on the underlying reasons for director appointments to these committees and the professional expertise of these directors. To ensure that our findings are econometrically robust, we employ various market models, event windows and statistical significance tests in the event study.

Corporate governance research on committees of boards of public firms in developed countries generally focuses on corporate governance and nominating committees, compensation committees and audit committees, probably as a result of the fact that these are the most common committees established by companies. However, the most common committees of boards in public firms quoted at the BIST are audit committees, corporate governance committees and early determination of risk committees (Arioglu and Tuan, 2014). The main responsibilities of members of audit committees are related to independent auditing of companies, preparation of financial statements, coordination of external auditors and internal control mechanisms, and prevention of fraud. On the other hand, corporate governance committee members' main responsibilities could be stated as ensuring the compliance of companies with the Principles of Corporate Governance (PCG) of Turkey and advising boards of directors to promote the improvement of corporate governance practices of their companies. Lastly, the main responsibilities of (early determination of) risk committee members could be stated as the identification of potential risks that companies might be subject to in the future and the potential ways to cope with these risks. It is difficult and unnecessary to argue which one of these committees' responsibilities is most vital for companies. What is important is that these committees function effectively, which depends on the members of these committees performing their monitoring duties effectively (Klein, 1998, Deli and Gillan; 2000). For example, effectively functioning audit committees could be vital in the prevention of fraudulent actions that would affect firm value negatively (Klein, 2002; Uzun et al., 2004). In the case of governance committees, effective functioning of these committees could be beneficial for companies especially in the process of nominating board members that could improve the quality of decisions regarding various corporate issues and not be influenced by chairmen or CEOs, who would be willing to work with directors that would not challenge their decisions (Borokhovich et al., 1996; Shivdasani and Yermack, 1999). Also, the members of risk committees bear important responsibilities in the detection of any potential risks that could arise as a result of the decisions made in boardrooms.

As mentioned earlier, one of the important characteristics of committee members that would affect their effectiveness in performing their duties in the committees is their professional expertise (Xie et al., 2003; Tao and Hutchinson, 2013). Directors such as financial and accounting experts could be very beneficial resources not only in audit committees as a result of their specific skills and experience, but they could also be beneficial in the assessment of potential risks that companies might be subject to. 
On the other hand, academicians could be very helpful in these committees especially if their field of research is relevant. For example a business professor would be expected to have scientific information related to finance, accounting, management or risk assessment topics among others. Therefore, these skills could be valuable for the improvement of corporate governance practices of companies, as well as for the functioning of audit and risk committees. In addition, lawyers in these committees could be especially beneficial especially in the compliance of companies with corporate governance regulations, as well as identifying potential risks of any future lawsuits. All these examples point out to the importance of technical skills and professional expertise of directors in board committees. Yet, it should be kept in mind that these experts, who are not executives of companies, might lack valuable firm-specific information (Litov et al., 2014). In empirical studies, Choi et al. (2014) provide evidence suggesting that the characteristics of the members of audit committees could alter the soundness of corporate governance structure of firms. Studies such as Agrawal and Chadha (2005) and Albring et al. (2014) provide supportive evidence of the importance of committee member expertise arguments. On the other hand, Defond et al. (2005) show that markets react positively to the existence of accounting financial experts on audit committees, whereas Chakrabati and Sarkar (2010) show that Indian markets do not value the financial expertise of directors in audit committees.

\section{DATA AND METHODOLOGY}

The committee establishments sample covers the establishments of 111 risk committees, 43 governance committees and 16 audit committees by public companies quoted at the Borsa Istanbul (BIST) during the January 1, 2012 to June 30, 2014 period. On the other hand, committee member appointments sample includes the appointments of 300 risk committee, 164 governance committee and 112 audit committee members. Lastly, committee member departures sample covers the departures of 36 risk committee, 52 governance committee and 42 audit committee members. The reason that the number of committee member appointments is substantially higher than the number of committee member departures is the sample period chosen. Before the sample period, the Principles of Corporate Governance (PCG) in Turkey was not effective. The PCG, which could be considered the corporate governance reform of Turkey, imposed various requirements such as the establishment of board committees and the ratio of independent directors that must serve on these committees. Consequently, the majority of public firms either established new committees or restructured the existing ones. The directors included in the samples are committee members that are also members of boards of directors. For example, an individual, who is the manager of investor relations department, serving on the governance committee is not included in the sample. This is because our focus and arguments are on the effectiveness of board members serving on committee of boards. In addition, board members are relatively more public figures compared to non-board member executives of companies and many companies do not provide background information for lower level executives, whereas the majority of them provide detailed information about board members. 
Since investors would be expected to react to new information and price it when it becomes available, if not earlier as a result of leakages, we investigate the market reaction surrounding the announcements of committee establishments and member appointments and departures. The announcements are identified via reading all the news submitted to the Public Disclosure Platform (PDP) by firms during the sample period. Any committee establishment or member appointment/departure that is not announced by public firms to the PDP is not included in the samples. In addition, only isolated announcements are included in the samples in order to separately measure the effect of each announcement on stock prices. On the other hand, announcements by financial firms are not included in the samples because we employ the 4 Factor Model (4FM) and the 3 Factor Model (3FM) in expected return estimations.

Data required to estimate expected returns and to calculate abnormal returns are gathered from official data providers such as Finnet, Is Yatirim and Borsa Istanbul's official webpage. Data regarding director expertise are hand-collected via annual reports and official webpages of companies. For daily and monthly stock returns calculations, adjusted price series were utilized as opposed to raw price series Basdas and Oran (2014).

To investigate the market reaction to various announcements abnormal returns (ARs), average abnormal returns (AARs), and cumulative average abnormal returns (CAARs) are required. CAAR can be denoted as:

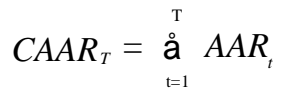

where,

$$
A A R_{t}=\frac{1}{N} \underset{i=1}{N} A R_{i, t}
$$

and,

$$
A R_{i, t}=R_{i, t}-E\left(R_{i, t}\right)
$$

As can be observed in equation (1), expected returns $E(R) s$ are also required. Expected returns can be estimated by utilizing various models. Majority of the studies that conduct event studies for Turkish capital markets employ models such as the capital asset pricing model or the simple market model, as well as market adjusted returns. On the other hand, Tahaoglu and Guner (2011) employ the 3FM. In this study we employ the 4FM in order to estimate expected returns. 4FM developed in Carhart (1997) incorporates the momentum factor into the 3FM developed in Fama and French (1993). In addition to size and book-tomarket anomalies, the 4FM captures the momentum anomaly in Jegadeesh and Titman (1993). Ahern (2009) argues that this model outperforms models such as the capital asset pricing models and generates returns that are less skewed. 
Unlu (2012) shows that the 4FM captures variations in stock returns of Borsa Istanbul firms as well. The model can be stated as (Kosowski et al., 2006; Fama and French, 2012):

$$
R_{i(m)}-R f_{(m)}=a_{i}+b_{i}\left(R M_{(m)}-R f_{(m)}\right)+s_{i} S M B_{(m)}+h_{i} H M L_{(m)}+m_{i} M O M_{(m)}+e_{i(m)}
$$

where, the RM above denotes the daily returns for the market return; average daily return for the BIST index that includes all the firms quoted at BIST. RF denotes the daily risk-free rate of returns. SMB, HML and MOM denote the returns for the size, book-to-market, and momentum factors. Since the focus of this study is not these models, readers interested in the details of this model can consult Carhart (1997), Fama and French (2012).

Based on this model, coefficients for each firm's stock are estimated in the 240 previous days estimation window following previous studies (Giroud and Mueller, 2010; Falato et al., 2014) and then utilized to estimate expected returns. The estimation window does not include the days immediately prior to the event and does not intersect with the event windows (Ahern, 2009), which are set as $(-10,+10),(-5,+5),(-1,+1)$ and $(0)$ for robustness purposes. After calculating CAARs in various event windows, we investigate whether these CAARs are statistically significantly different from zero by employing various significance tests. For robustness purposes, we test the significance of CAARs via the parametric cross sectional t-test and Boehmer, Musumeci and Poulsen (BMP) tests and the non-parametric sign test. In the standard cross-sectional t-test, the test statistic below is utilized:

$t_{\text {CAAR }}=\sqrt{N} \frac{C A A R}{S_{\text {CAAR }}}$

where $\mathrm{S}_{\text {CAAR }}$ :

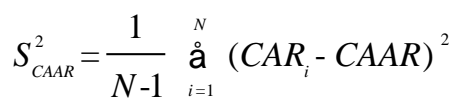

In addition, the test statistic for the BMP test is:

$$
z_{B M P}=\sqrt{N} \frac{\overline{S C A R}}{S_{\overline{S C A R}}}
$$

where:

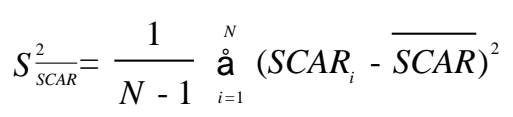

and: 
$\overline{S C A R}=\frac{1}{N} \stackrel{\mathrm{a}}{i=1}_{i=1}^{N} S C A R_{i}$

(9)

Lastly, the test statistic for the sign test is (Cowan, 1992):

$$
t_{\text {sign }}=\sqrt{N} \frac{\hat{p}-0.5}{\sqrt{0.5(1-0.5)}}
$$

For robustness check, we also provide findings based on returns estimated via the 3FM, as well as returns estimated via the 4FM where the return of the BIST 100 index is used as the market return.

\section{RESULTS}

\subsection{Committee Establishments}

The findings regarding the market reaction surrounding the establishment of committees of boards are presented in Table 1 . The Table shows that the CAARs on the day of the announcements of audit committee, risk committee, and governance committee establishments are $0.42 \%, 0.11 \%$, and $0.46 \%$, respectively. Even though the market reaction to the establishments of these committees on the announcement days is positive, they are not statistically significant. Parallel findings are observed for the CAARs in the three days surrounding these announcements. The CAARs $(-1,+1)$ for the audit, risk, and governance committee establishment announcements are $0.97 \%, 0.11 \%$, and $0.73 \%$, respectively. Once again, none of these CAARs are statistically significant. As the event window extends to ten and twenty days surrounding these announcements, the direction of the market reaction becomes negative for some of the committees. However, none of the CAARs are statistically significant.

Based on the findings presented in Table 1, one cannot argue that markets value the existence of various committees of boards, even though some positive market reaction in the most immediate days surrounding the establishment of these committees for the first time is observed.

Our findings are robust to different expected return generating model specifications as can be observed in Appendix 1. 
Table 1: Board Committee Establishments

\begin{tabular}{|c|c|c|c|c|c|}
\hline & & & Cross- & & \\
\hline & $\begin{array}{r}\text { CAAR } \\
(0)\end{array}$ & $\begin{array}{l}\text { Number } \\
\text { of Events }\end{array}$ & $\begin{array}{r}\text { Sect. t- } \\
\text { test }\end{array}$ & $\begin{array}{r}\text { BMP } \\
\text { t-test }\end{array}$ & $\begin{array}{l}\text { Sign } \\
\text { Test }\end{array}$ \\
\hline Audit Committee & $0.421 \%$ & 16 & 0.66 & 0.89 & 0.00 \\
\hline Risk Committee & $0.113 \%$ & 111 & 0.38 & 1.16 & -0.28 \\
\hline Governance Committee & $0.464 \%$ & 43 & 1.13 & 1.25 & -0.45 \\
\hline & & & Cross- & & \\
\hline & $\begin{array}{r}\text { CAAR } \\
(-1,+1)\end{array}$ & $\begin{array}{l}\text { Number } \\
\text { of Events }\end{array}$ & $\begin{array}{r}\text { Sect. t- } \\
\text { test }\end{array}$ & $\begin{array}{c}\text { BMP } \\
\text { t-test }\end{array}$ & $\begin{array}{l}\text { Sign } \\
\text { Test }\end{array}$ \\
\hline Audit Committee & $0.976 \%$ & 16 & 1.61 & 0.89 & 1.00 \\
\hline Risk Committee & $0.112 \%$ & 111 & 0.26 & 0.96 & -0.66 \\
\hline Governance Committee & $0.734 \%$ & 43 & 1.30 & 1.03 & 0.45 \\
\hline & & & Cross- & & \\
\hline & $\begin{array}{r}\text { CAAR } \\
(-5,+5) \\
\end{array}$ & $\begin{array}{r}\text { Number } \\
\text { of Events }\end{array}$ & $\begin{array}{r}\text { Sect. t- } \\
\text { test }\end{array}$ & $\begin{array}{r}\text { BMP } \\
\text { t-test }\end{array}$ & $\begin{array}{l}\text { Sign } \\
\text { Test } \\
\end{array}$ \\
\hline Audit Committee & $0.618 \%$ & 16 & 0.57 & 0.12 & 0.50 \\
\hline Risk Committee & $-0.063 \%$ & 111 & -0.06 & 0.32 & -0.66 \\
\hline Governance Committee & $-0.279 \%$ & 43 & -0.34 & -0.41 & -1.06 \\
\hline & & & Cross- & & \\
\hline & $\begin{array}{r}\text { CAAR } \\
(-10,+10)\end{array}$ & $\begin{array}{l}\text { Number } \\
\text { of Events }\end{array}$ & $\begin{array}{r}\text { Sect. t- } \\
\text { test }\end{array}$ & $\begin{array}{r}\text { BMP } \\
\text { t-test }\end{array}$ & $\begin{array}{l}\text { Sign } \\
\text { Test }\end{array}$ \\
\hline Audit Committee & $0.682 \%$ & 16 & 0.50 & 0.35 & 0.50 \\
\hline Risk Committee & $-1.337 \%$ & 111 & -1.05 & -0.74 & -1.80 \\
\hline Governance Committee & $0.777 \%$ & 43 & 0.60 & 0.66 & 0.15 \\
\hline
\end{tabular}

4 Factor Model is employed to estimate expected returns for stocks. The return for the XTUM (the index that includes all the stocks traded at the BIST) is employed as the market return. The sample includes all the firms traded at the BIST.

\subsection{Committee Appointments}

Next, we investigate the market reaction surrounding the appointments of directors to various board committees based on the underlying reason for the appointments. The findings are presented in Table 2, Table 3 and Table 4. Table 2 shows that markets react negatively to director appointments to audit committees, if the appointments take place as a result of the PCG regulations. These are the regulations imposing that all members of audit committees are independent directors and therefore firms had to replace executive directors serving on audit committees with independent directors. Even though the CAARs in all the event windows are negative, they are statistically insignificant, except for the case of $\operatorname{CAAR}(-5,+5)$.

On the other hand, the results in Table 2 also suggest that markets appear to react positively to the appointments of directors to audit committees, when directors are appointed to these committees as a result of the voluntary establishment of the committee for the first time by companies. 
Yet, the CAARs do not appear to be statistically significant, except in the case of CAAR($1,+1)$ for which different significance tests provide contradicting significance levels. These findings should not be surprising based on the results presented in Table 1 that investors in Turkish capital markets do not value the establishment of committees in boards.

Lastly, the findings in Table 2 suggest that markets react positively to audit committee director appointments in the most immediate announcement days in the case that the director is appointed to replace a member that has left the committee. In the longer event windows, the CAARs become negative. However, none of the CAARs are statistically significant.

Next we present our findings regarding the market reaction to the announcements of member appointments to risk committees based on the underlying reasons in Table 3 . What is observed in the Table is that the CAARs for these announcements based on various underlying reasons are mixed in terms of the direction of the reaction, for various event windows. However, none of the CAARs are statistically significant at $95 \%$ level. These figures suggest that markets do not value the appointments of directors to risk committees irrelevant of the underlying reason for the appointments, whether they are results of the PCG regulations, first time committee establishments or replacements of previous directors.

Table 2: Audit Committee Appointments and Causes

\begin{tabular}{|c|c|c|c|c|c|}
\hline & & Number & Cross- & & \\
\hline & $\begin{array}{r}\text { CAAR } \\
(0)\end{array}$ & $\begin{array}{r}\text { of } \\
\text { Events }\end{array}$ & $\begin{array}{r}\text { Sect. } t- \\
\text { test }\end{array}$ & $\begin{array}{r}\text { BMP } \\
\text { t-test }\end{array}$ & $\begin{array}{l}\text { Sign } \\
\text { Test }\end{array}$ \\
\hline PCG Regulation & $-0.092 \%$ & 40 & -0.57 & -0.97 & -0.31 \\
\hline First Time Committee Establishment & $0.498 \%$ & 30 & 1.07 & 1.38 & 0.36 \\
\hline \multirow[t]{3}{*}{ Previous One Left } & $0.418 \%$ & 42 & 0.88 & 0.47 & 0.92 \\
\hline & & Number & Cross- & & \\
\hline & $\begin{array}{r}\text { CAAR } \\
(-1,+1) \\
\end{array}$ & $\begin{array}{r}\text { of } \\
\text { Events } \\
\end{array}$ & $\begin{array}{r}\text { Sect. t- } \\
\text { test }\end{array}$ & $\begin{array}{r}\text { BMP } \\
\text { t-test }\end{array}$ & $\begin{array}{l}\text { Sign } \\
\text { Test }\end{array}$ \\
\hline PCG Regulation & $-0.444 \%$ & 40 & -1.42 & -1.58 & -1.89 \\
\hline First Time Committee Establishment & $1.089 \%$ & 30 & 2.46 & 1.39 & 1.82 \\
\hline \multirow[t]{3}{*}{ Previous One Left } & $0.063 \%$ & 42 & 0.12 & -0.53 & -0.30 \\
\hline & & Number & Cross- & & \\
\hline & $\begin{array}{r}\text { CAAR } \\
(-5,+5)\end{array}$ & $\begin{array}{r}\text { of } \\
\text { Events }\end{array}$ & $\begin{array}{r}\text { Sect. t- } \\
\text { test }\end{array}$ & $\begin{array}{l}\text { BMP } \\
\text { t-test }\end{array}$ & $\begin{array}{l}\text { Sign } \\
\text { Test }\end{array}$ \\
\hline PCG Regulation & $-2.506 \%$ & 40 & -3.13 & -3.34 & -3.16 \\
\hline First Time Committee Establishment & $0.983 \%$ & 30 & 1.31 & 0.55 & 1.09 \\
\hline \multirow[t]{2}{*}{ Previous One Left } & $-2.030 \%$ & 42 & -0.93 & -1.05 & -0.30 \\
\hline & $\begin{array}{r}\text { CAAR } \\
(- \\
10,+10)\end{array}$ & $\begin{array}{r}\text { Number } \\
\text { of } \\
\text { Events }\end{array}$ & $\begin{array}{r}\text { Cross- } \\
\text { Sect. t- } \\
\text { test } \\
\end{array}$ & $\begin{array}{r}\text { BMP } \\
\text { t-test }\end{array}$ & $\begin{array}{l}\text { Sign } \\
\text { Test }\end{array}$ \\
\hline PCG Regulation & $-0.691 \%$ & 40 & -0.68 & -1.12 & 0.00 \\
\hline First Time Committee Establishment & $0.706 \%$ & 30 & 0.70 & 0.48 & 0.36 \\
\hline Previous One Left & $-3.255 \%$ & 42 & -1.26 & -1.34 & -1.23 \\
\hline
\end{tabular}


4 Factor Model is employed to estimate expected returns for stocks. The return for the XTUM (the index that includes all the stocks traded at the BIST) is employed as the market return. The sample includes all the firms traded at the BIST.

Table 3: Risk Committee Appointments and Causes

\begin{tabular}{|c|c|c|c|c|c|c|}
\hline & & $\begin{array}{r}\text { CAAR } \\
(0)\end{array}$ & $\begin{array}{r}\text { Numbe } \\
r \text { of } \\
\text { Events }\end{array}$ & $\begin{array}{r}\text { Cross- } \\
\text { Sect. t- } \\
\text { test }\end{array}$ & $\begin{array}{r}\text { BMP } \\
\text { t-test }\end{array}$ & $\begin{array}{l}\text { Sign } \\
\text { Test }\end{array}$ \\
\hline \multicolumn{2}{|l|}{ PCG Regulation } & $2.095 \%$ & 8 & -1.07 & -0.44 & -0.70 \\
\hline First Time & Committee & & & & & \\
\hline \multirow{2}{*}{\multicolumn{2}{|c|}{ Establishment }} & $0.078 \%$ & 265 & 0.41 & 1.61 & -0.55 \\
\hline & & - & & & & \\
\hline \multirow[t]{3}{*}{ Previous One Left } & & $0.062 \%$ & 27 & -0.13 & -0.19 & 0.96 \\
\hline & & $\begin{array}{r}\text { CAAR } \\
(-1,+1) \\
\end{array}$ & $\begin{array}{r}\text { Numbe } \\
r \text { of } \\
\text { Events }\end{array}$ & $\begin{array}{r}\text { Cross- } \\
\text { Sect. t- } \\
\text { test }\end{array}$ & $\begin{array}{r}\text { BMP } \\
\text { t-test }\end{array}$ & $\begin{array}{l}\text { Sign } \\
\text { Test }\end{array}$ \\
\hline & & - & & & & \\
\hline \multicolumn{2}{|l|}{ PCG Regulation } & $0.848 \%$ & 8 & -0.80 & 0.14 & 0.00 \\
\hline First Time & Committee & & & & & \\
\hline \multirow{2}{*}{\multicolumn{2}{|c|}{$\begin{array}{l}\text { Establishment } \\
\text { Previous One Left }\end{array}$}} & $0.131 \%$ & 265 & 0.44 & 1.65 & -0.67 \\
\hline & & $0.269 \%$ & 27 & 0.49 & 0.29 & 0.96 \\
\hline & & & Numbe & Cross- & & \\
\hline & & $\begin{array}{r}\text { CAAR } \\
(-5,+5) \\
\end{array}$ & $\begin{array}{r}r \text { of } \\
\text { Events }\end{array}$ & $\begin{array}{r}\text { Sect. t- } \\
\text { test }\end{array}$ & $\begin{array}{r}\text { BMP } \\
\text { t-test }\end{array}$ & $\begin{array}{l}\text { Sign } \\
\text { Test }\end{array}$ \\
\hline & & - & & & & \\
\hline \multicolumn{2}{|l|}{ PCG Regulation } & $0.074 \%$ & 8 & -0.05 & 0.39 & -1.41 \\
\hline First Time & Committee & - & & & & \\
\hline \multirow{2}{*}{\multicolumn{2}{|c|}{$\begin{array}{l}\text { Establishment } \\
\text { Previous One Left }\end{array}$}} & $0.112 \%$ & 265 & -0.19 & 0.49 & -0.30 \\
\hline & & $2.124 \%$ & 27 & 1.65 & 2.29 & 1.73 \\
\hline & & $\begin{array}{r}\text { CAAR } \\
(- \\
10,+10)\end{array}$ & $\begin{array}{r}\text { Numbe } \\
r \text { of } \\
\text { Events }\end{array}$ & $\begin{array}{r}\text { Cross- } \\
\text { Sect. t- } \\
\text { test }\end{array}$ & $\begin{array}{r}\text { BMP } \\
\text { t-test }\end{array}$ & $\begin{array}{l}\text { Sign } \\
\text { Test }\end{array}$ \\
\hline \multicolumn{2}{|l|}{ PCG Regulation } & $1.401 \%$ & 8 & 1.84 & 1.73 & 2.12 \\
\hline First $\quad$ Time & Committee & - & & & & \\
\hline \multirow{2}{*}{\multicolumn{2}{|c|}{$\begin{array}{l}\text { Establishment } \\
\text { Previous One Left }\end{array}$}} & $1.543 \%$ & 265 & -1.90 & -1.21 & -3.25 \\
\hline & & $2.353 \%$ & 27 & 1.26 & 1.88 & 0.96 \\
\hline
\end{tabular}

4 Factor Model is employed to estimate expected returns for stocks. The return for the XTUM (the index that includes all the stocks traded at the BIST) is employed as the market return. The sample includes all the firms traded at the BIST.

Lastly, we present our findings regarding the market reaction to the announcements of director appointments to governance committees. The results are presented in Table 4. We observe parallel findings to those in Table 2 and Table 3. 
Once again, the CAARs for various underlying appointment reasons are mixed in terms of the direction of the reaction for various event windows, and they are statistically insignificant except for $\operatorname{CAAR}(-5,+5)$ for director appointments as a result of the PCG regulations.

Table 4: Governance Committee Appointments and Causes

\begin{tabular}{|c|c|c|c|c|c|}
\hline & $\begin{array}{r}\text { CAAR } \\
(0)\end{array}$ & $\begin{array}{r}\text { Numbe } \\
r \text { of } \\
\text { Events }\end{array}$ & $\begin{array}{r}\text { Cross- } \\
\text { Sect. t- } \\
\text { test }\end{array}$ & $\begin{array}{r}\text { BMP } \\
\text { t-test }\end{array}$ & $\begin{array}{l}\text { Sign } \\
\text { Test }\end{array}$ \\
\hline PCG Regulation & $0.297 \%$ & 22 & 1.04 & 0.95 & 0.00 \\
\hline First Time Committee Establishment & $0.456 \%$ & 98 & 1.74 & 1.80 & -1.01 \\
\hline \multirow[t]{2}{*}{ Previous One Left } & $-0.255 \%$ & 44 & -0.68 & -0.75 & -0.60 \\
\hline & $\begin{array}{r}\text { CAAR } \\
(-1,+1) \\
\end{array}$ & $\begin{array}{r}\text { Numbe } \\
r \text { of } \\
\text { Events }\end{array}$ & $\begin{array}{r}\text { Cross- } \\
\text { Sect. t- } \\
\text { test }\end{array}$ & $\begin{array}{r}\text { BMP } \\
\text { t-test }\end{array}$ & $\begin{array}{l}\text { Sign } \\
\text { Test }\end{array}$ \\
\hline PCG Regulation & $-0.316 \%$ & 22 & -0.87 & -0.46 & -0.42 \\
\hline First Time Committee Establishment & $0.578 \%$ & 98 & 1.60 & 0.98 & 0.40 \\
\hline \multirow[t]{2}{*}{ Previous One Left } & $-0.724 \%$ & 44 & -1.84 & -1.72 & -1.20 \\
\hline & $\begin{array}{r}\text { CAAR } \\
(-5,+5)\end{array}$ & $\begin{array}{r}\text { Numbe } \\
r \text { of } \\
\text { Events }\end{array}$ & $\begin{array}{r}\text { Cross- } \\
\text { Sect. t- } \\
\text { test }\end{array}$ & $\begin{array}{r}\text { BMP } \\
\text { t-test }\end{array}$ & $\begin{array}{l}\text { Sign } \\
\text { Test }\end{array}$ \\
\hline PCG Regulation & $-3.128 \%$ & 22 & -3.12 & -2.77 & -3.41 \\
\hline First Time Committee Establishment & $0.221 \%$ & 98 & 0.40 & 0.24 & -0.80 \\
\hline \multirow[t]{2}{*}{ Previous One Left } & $-0.477 \%$ & 44 & -0.27 & -0.21 & 0.30 \\
\hline & $\begin{array}{r}\text { CAAR } \\
(- \\
10,+10)\end{array}$ & $\begin{array}{r}\text { Numbe } \\
r \text { of } \\
\text { Events }\end{array}$ & $\begin{array}{r}\text { Cross- } \\
\text { Sect. t- } \\
\text { test }\end{array}$ & $\begin{array}{r}\text { BMP } \\
\text { t-test }\end{array}$ & $\begin{array}{l}\text { Sign } \\
\text { Test }\end{array}$ \\
\hline PCG Regulation & $0.069 \%$ & 22 & 0.06 & 0.31 & 0.42 \\
\hline First Time Committee Establishment & $1.049 \%$ & 98 & 1.20 & 1.18 & -0.20 \\
\hline Previous One Left & $-1.252 \%$ & 44 & -0.61 & -0.48 & -0.30 \\
\hline
\end{tabular}

4 Factor Model is employed to estimate expected returns for stocks. The return for the XTUM (the index that includes all the stocks traded at the BIST) is employed as the market return. The sample includes all the firms traded at the BIST.

Based on the overall evidence presented in Table 2, Table 3 and Table 4, one cannot suggest that investors in Turkish capital markets value the appointments of directors to various committees of boards. Our findings are robust to different expected return generating model specifications as can be observed in Appendix 1.

\subsection{Committee Member Expertise}

Another issues we investigate is the market reaction to director appointments to (departures from) various committees of boards based on the professional expertise of directors. As discussed earlier, the professional expertise of committee members would be an important determinant of the effectiveness of committee functioning. 
In this section, we define a director as an expert if she is either a financial expert, an accounting expert, a lawyer or an academician. A director with none of these professional backgrounds is defined as a non-expert director. A detailed discussion of benefits and costs associated with the existence of these professional on corporate boards can be found in Arioglu (2014).

Our findings are presented in Table 5, Table 6 and Table 7. Table 5 shows that the market reaction to the announcements of appointments of expert directors to audit committee is positive. On the other hand, market reaction to the departures of these expert directors is negative in all the event windows, except in the three days surrounding the departures. Yet, none of these CAARs are statistically significant. However, when we compare the CAARs surrounding expert director appointments to CAARs surrounding non-expert director appointments, we observe that in the three, ten and twenty days surrounding the announcements of appointments, the CAARs are statistically significantly higher for expert director appointment announcements. Yet, we do not observe a similar pattern for expert director departures and non-expert director departures.

Table 5: Audit Committee Member Changes: Expertise

\begin{tabular}{|c|c|c|c|c|c|}
\hline & & Number & Cross- & & \\
\hline & $\begin{array}{r}\text { CAAR } \\
(0) \\
\end{array}$ & $\begin{array}{r}\text { of } \\
\text { Events }\end{array}$ & $\begin{array}{r}\text { Sect. } t- \\
\text { test }\end{array}$ & $\begin{array}{r}\text { BMP } \\
\text { t-test }\end{array}$ & $\begin{array}{l}\text { Sign } \\
\text { Test }\end{array}$ \\
\hline Expert Appointment & $0.120 \%$ & 62 & 0.41 & 0.46 & 1.27 \\
\hline Expert Departure & $-0.225 \%$ & 28 & -0.32 & -0.79 & 0.37 \\
\hline Non-Expert Appointment & $0.362 \%$ & 44 & 0.89 & 0.79 & -0.30 \\
\hline \multirow[t]{3}{*}{ Non-Expert Departure } & $-0.496 \%$ & 14 & -0.53 & -0.22 & 0.53 \\
\hline & $\begin{array}{r}\text { CAAR } \\
(-1,+1) \\
\end{array}$ & $\begin{array}{r}\text { Number } \\
\text { of } \\
\text { Events } \\
\end{array}$ & $\begin{array}{r}\text { Cross- } \\
\text { Sect. t- } \\
\text { test }\end{array}$ & $\begin{array}{c}\text { BMP } \\
\text { t-test }\end{array}$ & $\begin{array}{l}\text { Sign } \\
\text { Test } \\
\end{array}$ \\
\hline & $* * * 0.562$ & & & & \\
\hline Expert Appointment & $\%$ & 62 & 1.48 & 1.04 & 2.03 \\
\hline Expert Departure & $0.363 \%$ & 28 & 0.52 & 0.20 & 1.13 \\
\hline Non-Expert Appointment & $-0.656 \%$ & 44 & -1.48 & -2.35 & -2.71 \\
\hline \multirow[t]{4}{*}{ Non-Expert Departure } & $-1.511 \%$ & 14 & -1.19 & -1.21 & -0.53 \\
\hline & & Number & Cross- & & \\
\hline & $\begin{array}{r}\text { CAAR } \\
(-5,+5) \\
\end{array}$ & $\begin{array}{r}\text { of } \\
\text { Events } \\
\end{array}$ & $\begin{array}{r}\text { Sect. } t- \\
\text { test }\end{array}$ & $\begin{array}{r}\text { BMP } \\
\text { t-test }\end{array}$ & $\begin{array}{l}\text { Sign } \\
\text { Test }\end{array}$ \\
\hline & $* * * 0.818$ & & & & \\
\hline Expert Appointment & $\%$ & 62 & 0.83 & 0.53 & 0.50 \\
\hline Expert Departure & $-3.041 \%$ & 28 & -1.43 & -1.27 & -1.51 \\
\hline Non-Expert Appointment & $-4.139 \%$ & 44 & -2.28 & -2.59 & -2.11 \\
\hline \multirow[t]{3}{*}{ Non-Expert Departure } & $-5.061 \%$ & 14 & -1.17 & -1.29 & 0.00 \\
\hline & & Number & Cross- & & \\
\hline & $\begin{array}{r}\text { CAAR } \\
(-10,+10)\end{array}$ & $\begin{array}{r}\text { of } \\
\text { Events }\end{array}$ & $\begin{array}{r}\text { Sect. } t- \\
\text { test }\end{array}$ & $\begin{array}{c}\text { BMP } \\
\text { t-test }\end{array}$ & $\begin{array}{l}\text { Sign } \\
\text { Test }\end{array}$ \\
\hline Expert Appointment & $* * 0.714 \%$ & 62 & 0.63 & 0.33 & -0.25 \\
\hline Expert Departure & $-5.570 \%$ & 28 & -1.73 & -1.64 & -2.26 \\
\hline Non-Expert Appointment & $-3.555 \%$ & 44 & -1.54 & -1.67 & -0.60 \\
\hline Non-Expert Departure & $-4.872 \%$ & 14 & -0.93 & -0.91 & -0.53 \\
\hline
\end{tabular}


4 Factor Model is employed to estimate expected returns for stocks. The return for the XTUM (the index that includes all the stocks traded at the BIST) is employed as the market return. The sample includes all the firms traded at the BIST. The CAARs are compared for directors that are considered experts and that are not. The significance levels based on Wilcoxon signed-rank tests are reported. ${ }^{*}, * *$, and $* * *$ present significance at $10 \%, 5 \%$, and $1 \%$ levels.

Next, in Table 6, we present the findings regarding the market reaction to the appointments and departures of expert and non-expert directors for risk committees. The Table presents mixed results in terms of the signs of the market reactions. The investors in Turkish capital markets do not appear to react to the appointments or departures of expert or non-expert directors for risk committees. None of the CAARs surrounding the announcements of these events are statistically significant. In addition, the comparison of CAARs between expert and non-expert director appointments and departures do not yield any significant difference for these groups at $95 \%$ level. Based on these findings, one can argue that investors in Turkish capital markets value the professional expertise of directors in risk committees of public companies.

Lastly, we present market reaction surrounding the appointments and departures of expert end non-expert directors for governance committees in Table 7. The signs of the CAARs for expert director appointments to governance committees are mixed for different event windows, whereas it is negative for expert director departures from these committees. However, the CAARs for neither expert appointments nor expert departures are statistically significant. When we compare the CAARs for expert director appointments and departures, with the appointments and departures of non-expert directors, we do not observe statistically different significances at $95 \%$ levels. 
Table 6: Risk Committee Member Changes: Expertise

\begin{tabular}{|c|c|c|c|c|c|}
\hline & & Numbe & Cross- & & \\
\hline & $\begin{array}{r}\text { CAAR } \\
(0) \\
\end{array}$ & $\begin{array}{r}r \text { of } \\
\text { Events }\end{array}$ & $\begin{array}{r}\text { Sect. t- } \\
\text { test }\end{array}$ & $\begin{array}{r}\text { BMP } \\
\text { t-test }\end{array}$ & $\begin{array}{l}\text { Sign } \\
\text { Test }\end{array}$ \\
\hline Expert Appointment & $-0.048 \%$ & 166 & -0.21 & 0.49 & -0.93 \\
\hline Expert Departure & $-0.406 \%$ & 27 & -0.93 & -0.48 & 0.57 \\
\hline Non-Expert Appointment & $0.122 \%$ & 108 & 0.34 & 1.63 & 0.96 \\
\hline \multirow[t]{3}{*}{ Non-Expert Departure } & $0.555 \%$ & 9 & 1.10 & 1.38 & 1.00 \\
\hline & & Numbe & Cross- & & \\
\hline & $\begin{array}{r}\text { CAAR } \\
(-1,+1) \\
\end{array}$ & $\begin{array}{r}r \text { of } \\
\text { Events }\end{array}$ & $\begin{array}{r}\text { Sect. t- } \\
\text { test }\end{array}$ & $\begin{array}{c}\text { BMP } \\
\text { t-test }\end{array}$ & $\begin{array}{l}\text { Sign } \\
\text { Test }\end{array}$ \\
\hline Expert Appointment & $0.123 \%$ & 166 & 0.40 & 1.37 & 0.15 \\
\hline Expert Departure & $0.251 \%$ & 27 & 0.54 & 0.25 & 0.96 \\
\hline Non-Expert Appointment & $0.246 \%$ & 108 & 0.42 & 1.27 & 0.00 \\
\hline \multirow[t]{3}{*}{ Non-Expert Departure } & $-0.136 \%$ & 9 & -0.22 & 0.31 & -0.33 \\
\hline & & Numbe & Cross- & & \\
\hline & $\begin{array}{r}\text { CAAR } \\
(-5,+5)\end{array}$ & $\begin{array}{r}r \text { of } \\
\text { Events }\end{array}$ & $\begin{array}{r}\text { Sect. t- } \\
\text { test }\end{array}$ & $\begin{array}{r}\text { BMP } \\
\text { t-test }\end{array}$ & $\begin{array}{l}\text { Sign } \\
\text { Test }\end{array}$ \\
\hline Expert Appointment & $0.100 \%$ & 166 & 0.16 & 0.68 & 0.46 \\
\hline Expert Departure & $0.196 \%$ & 27 & 0.15 & 0.36 & -0.96 \\
\hline Non-Expert Appointment & $-0.146 \%$ & 108 & -0.13 & 0.58 & -0.19 \\
\hline \multirow[t]{3}{*}{ Non-Expert Departure } & $-2.687 \%$ & 9 & -1.42 & -1.07 & -0.33 \\
\hline & & Numbe & Cross- & & \\
\hline & $\begin{array}{r}\text { CAAR } \\
(-10,+10)\end{array}$ & $\begin{array}{r}r \text { of } \\
\text { Events }\end{array}$ & $\begin{array}{r}\text { Sect. t- } \\
\text { test }\end{array}$ & $\begin{array}{r}\text { BMP } \\
\text { t-test }\end{array}$ & $\begin{array}{l}\text { Sign } \\
\text { Test }\end{array}$ \\
\hline Expert Appointment & $-0.472 \%$ & 166 & -0.54 & -0.60 & -2.17 \\
\hline Expert Departure & $* 2.152 \%$ & 27 & 0.76 & 0.82 & 0.57 \\
\hline Non-Expert Appointment & $-1.698 \%$ & 108 & -1.10 & -0.35 & -0.96 \\
\hline Non-Expert Departure & $-3.775 \%$ & 9 & -1.18 & -0.79 & -1.00 \\
\hline
\end{tabular}

4 Factor Model is employed to estimate expected returns for stocks. The return for the XTUM (the index that includes all the stocks traded at the BIST) is employed as the market return. The sample includes all the firms traded at the BIST. The CAARs are compared for directors that are considered experts and that are not. The significance levels based on Wilcoxon signed-rank tests are reported. $*, * *$, and $* * *$ present significance at $10 \%, 5 \%$, and $1 \%$ levels. 
Table 7: Governance Committee Member Changes: Expertise

\begin{tabular}{|c|c|c|c|c|c|}
\hline & & Numbe & Cross- & & \\
\hline & $\begin{array}{r}\text { CAAR } \\
(0)\end{array}$ & $\begin{array}{r}r \text { of } \\
\text { Events }\end{array}$ & $\begin{array}{r}\text { Sect. t- } \\
\text { test }\end{array}$ & $\begin{array}{r}\text { BMP } \\
\text { t-test }\end{array}$ & $\begin{array}{l}\text { Sign } \\
\text { Test }\end{array}$ \\
\hline Expert Appointment & $0.102 \%$ & 76 & 0.37 & 0.77 & -1.14 \\
\hline Expert Departure & $*-0.234 \%$ & 30 & -0.52 & -0.01 & 1.09 \\
\hline Non-Expert Appointment & $0.288 \%$ & 86 & 1.02 & 1.00 & -0.64 \\
\hline \multirow[t]{2}{*}{ Non-Expert Departure } & $-0.995 \%$ & 22 & -1.92 & -1.73 & -1.70 \\
\hline & $\begin{array}{r}\text { CAAR } \\
(-1,+1) \\
\end{array}$ & $\begin{array}{r}\text { Numbe } \\
r \text { of } \\
\text { Events }\end{array}$ & $\begin{array}{r}\text { Cross- } \\
\text { Sect. t- } \\
\text { test }\end{array}$ & $\begin{array}{c}\text { BMP } \\
\text { t-test }\end{array}$ & $\begin{array}{l}\text { Sign } \\
\text { Test }\end{array}$ \\
\hline Expert Appointment & $-0.087 \%$ & 76 & -0.22 & -0.10 & 0.00 \\
\hline Expert Departure & $-0.185 \%$ & 30 & -0.41 & -0.31 & -0.36 \\
\hline Non-Expert Appointment & $0.195 \%$ & 86 & 0.55 & -0.11 & -0.64 \\
\hline \multirow[t]{2}{*}{ Non-Expert Departure } & $-1.476 \%$ & 22 & -1.67 & -1.19 & -0.85 \\
\hline & $\begin{array}{r}\text { CAAR } \\
(-5,+5)\end{array}$ & $\begin{array}{r}\text { Numbe } \\
r \text { of } \\
\text { Events }\end{array}$ & $\begin{array}{r}\text { Cross- } \\
\text { Sect. t- } \\
\text { test }\end{array}$ & $\begin{array}{r}\text { BMP } \\
\text { t-test }\end{array}$ & $\begin{array}{l}\text { Sign } \\
\text { Test }\end{array}$ \\
\hline Expert Appointment & $-0.188 \%$ & 76 & -0.02 & 0.16 & -0.91 \\
\hline Expert Departure & $-0.531 \%$ & 30 & -0.52 & -0.75 & -1.46 \\
\hline Non-Expert Appointment & $-0.644 \%$ & 86 & -0.71 & -0.76 & -1.07 \\
\hline \multirow[t]{2}{*}{ Non-Expert Departure } & $-0.389 \%$ & 22 & -1.43 & -1.28 & -1.27 \\
\hline & $\begin{array}{r}\text { CAAR } \\
(-10,+10)\end{array}$ & $\begin{array}{r}\text { Numbe } \\
r \text { of } \\
\text { Events }\end{array}$ & $\begin{array}{r}\text { Cross- } \\
\text { Sect. t- } \\
\text { test }\end{array}$ & $\begin{array}{r}\text { BMP } \\
\text { t-test }\end{array}$ & $\begin{array}{l}\text { Sign } \\
\text { Test }\end{array}$ \\
\hline Expert Appointment & $0.427 \%$ & 76 & 0.42 & 0.83 & 0.00 \\
\hline Expert Departure & $*-0.646 \%$ & 30 & -0.37 & -0.10 & 0.00 \\
\hline Non-Expert Appointment & $0.793 \%$ & 86 & 0.64 & 0.73 & 0.64 \\
\hline Non-Expert Departure & $-4.859 \%$ & 22 & -1.51 & -1.31 & -1.70 \\
\hline
\end{tabular}

4 Factor Model is employed to estimate expected returns for stocks. The return for the XTUM (the index that includes all the stocks traded at the BIST) is employed as the market return. The sample includes all the firms traded at the BIST. The CAARs are compared for directors that are considered experts and that are not. The significance levels based on Wilcoxon signed-rank tests are reported. ${ }^{*}, * *$, and $* * *$ present significance at $10 \%, 5 \%$, and $1 \%$ levels.

Based on the overall evidence presented in the three Tables in this section, we cannot argue that investors in Turkish capital markets value the existence of expert director on various committees of boards. However, as the findings in Table 5 suggest, the markets react significantly higher to the announcements of appointments of directors with professional expertise to audit committees of boards, compared to the appointments or directors with no professional expertise. Our findings are robust to different expected return generating model specifications as can be observed in Appendix 2. 


\section{CONCLUSIONS}

As it is the case with other corporate governance mechanisms, committees of boards of directors have received attention in Turkish capital markets and finance literature investigating Turkish capital markets in the recent years (ownership structure is an exception). These committees are very important corporate governance mechanisms that could help firms improve the effectiveness of monitoring provided by boards of directors. Yet, research on these committees is very limited -mostly with a focus on audit committees- and does not consider whether investors in capital markets value the existence of these committees and the characteristics of members of these committees. In this study, we investigate the market reaction surrounding the establishments of committees of boards and director appointments to these committees based on the underlying reasons for the appointments in public firms quoted at the Borsa Istanbul. In addition, we investigate whether the market reaction varies based on the professional expertise of committee members.

Our findings suggest that markets do not appear to value the existence of various committees of boards, even though some positive market reaction in the most immediate days surrounding the establishment of these committees is observed. These results are surprising since they indicate that investors in Turkish capital markets do not value the existence of board committees, which could be expected to improve the effectiveness of monitoring provided by members of boards of directors, leading to increased firm value.

In addition, our findings suggest that investors in Turkish capital markets do not value the appointments of new directors to various committees of boards, no matter what the underlying reason is. It is hard to argue that one could expect to observe positive or negative market reaction surrounding the appointments of directors to board committees when the appointment takes place as a replacement of a previous committee member. Yet, if the PCG regulations are aimed at improving the level of corporate governance applications and we could expect the voluntary efforts of firms to improve the quality of their corporate governance applications to signal to markets that the rights of minority shareholders would be protected better, we could expect to observe positive market reaction surrounding the announcements of director appointments to board committees as a result of the PCG regulations and voluntary first time committee establishments. However, we do not observe such market reaction.

Lastly, our findings suggest that investors in Turkish capital markets do not value the existence of expert directors on various committees of boards. However, markets react significantly higher to the appointments of directors with professional expertise to audit committees of boards, compared to the appointments or directors with no professional expertise. This observation is in accordance with the fact that the majority of research on various committees of boards of public firms in Turkey focuses on audit committees, rather than risk or governance committees. After all, public companies have had internal audit mechanisms such as internal controllers and internal auditors that have been replaced with audit committees. However, they did not use to have specific mechanisms to control the riskiness of various aspects of companies' operations or any mechanisms to improve the corporate governance applications until recently. 
Overall, the evidence we provide in this study suggests that investors in Turkish capital markets do not value committees of boards highly, as opposed to the investors in more developed markets. This could potentially be explained by the fact that corporate governance is a relatively new concept in Turkish capital markets. Authorities in more developed countries have imposed various requirements on public firms to improve the quality of corporate governance practices in order to protect the rights of minority shareholders over a decade ago. However, such requirements are being imposed on Turkish public companies only in the most recent year following the effectiveness of the Principles of Corporate Governance.

In addition, these findings could be an outcome of the possibility that investors do not believe that corporate governance does actually matter in Turkish capital markets and legal requirements are met by companies on paper even though large controlling groups and families do not act in the best interest of small investors. No matter what the underlying reason is, more research should be conducted on corporate governance, which could help policymakers set legal requirements that would work effectively and help protect the benefits of small investors, if Turkey wants to provide such an investment environment that funds can be attracted to Turkish capital markets so that the country's economy can develop in a sound and healthy manner.

\section{REFERENCES}

- $\quad$ Agrawal, A. and Chadha, S. (2005), Corporate Governance and Accounting Scandals, Journal of Law and Economics, Vol.48, No.2, pp.371-406.

- $\quad$ Ahern, K. R. (2009), Sample Selection and Event Study Estimation, Journal of Empirical Finance, Vol.16, pp.466-482.

- $\quad$ Albring, S., Robinson, D. and Robinson, M. (2014), Audit Committee Financial Expertise, Corporate Governance and the Voluntary Switch from Auditorprovided to Non-auditor-provided Tax Services, Advances in Accounting, Vol.30, No.1, pp.81-94.

- Arioglu, E. (2014), Educated Professional on Boards at Borsa Istanbul, Journal of Business, Economics and Finance, Vol.3, No.3, pp.259-282.

- $\quad$ Arioglu, E. and Tuan, K. (2014), Characteristics of Members of Board Committees at Borsa Istanbul, International Journal of Economics and Finance, Vol.6, No.12, pp.83-94.

- Basdas, U. and Oran, A. (2014), Event Studies in Turkey, Borsa Istanbul Review, Vol.14, No.3, pp.167-188. 
- $\quad$ Borokhovich, K. A., Parrino, R. and Trapani, T. (1996), Outside Directors and CEO Selection, Journal of Financial and Quantitative Analysis, Vol.31, No.3, pp.337355.

- Carhart, M. M. (1997), On the Persistence in Mutual Fund Performance, Journal of Finance, Vol.52, No.1, pp.57-82.

- $\quad$ Chakrabati, R. and Sarkar, S. (2010), Corporate Governance in an Emerging Market - What Does the Market Trust?, Working Paper, (Abstract available at: http://ssrn.com/abstract=1615960).

- $\quad$ Choi, Y. K., Han, S. H. and Lee, S. (2014), Audit Committees, Corporate Governance, and Shareholder Wealth: Evidence from Korea, Journal of Accounting and Public Policy, Vol.33, No.5, pp.470-489.

- Cowan, A. R. (1992), Nonparametric Event Study Tests, Review of Quantitative Finance and Accounting, Vol.2, pp.343-358.

- Defond, M. L., Hann, R. N. and Hu, X. (2005), Does the Market Value Financial Expertise on Audit Committees of Boards of Directors, Journal of Accounting Research, Vol.43, No.2, pp.153-193.

- Deli, D. N. and Gillan, S. L. (2000), On the Demand for Independent and Active Audit Committees, Journal of Corporate Finance, Vol.6, No.4, pp.427-445.

- $\quad$ Falato, A., Kadyrzhanova, D. and Lel, U. (2014), Distracted Directors: Does Board Busyness Hurt Shareholder Value?, Journal of Financial Economics, Vol.11, pp.404-426.

- $\quad$ Fama, E. and French, K. (1993), Common Risk Factors in the Returns on Stocks and Bonds, Journal of Financial Economics, Vol.33, pp.3-56.

- Fama, E. and French, K. (2012), Size, Value, and Momentum in International Stock Returns, Journal of Financial Economics, Vol.105, pp.457-472.

- $\quad$ Giroud, X. and Mueller, H. M. (2010), Does Corporate Governance Matter in Competitive Industries?, Journal of Financial Economics, Vol.95, pp.312-331.

- Jegadeesh, N. and Titman, S. (1993), Returns to Buying Winners and Selling Losers: Implications for Stock Market Efficiency, Journal of Finance, Vol.48, No.1, pp.65-91. 
- Kandemir, T. and Akbulut, H. (2013), Bağımsız Denetimin Etkinliğinde Denetimden Sorumlu Komitenin Rolü: Türkiye'deki Bağımsız Denetim Firmalarına Yönelik Bir Araştırma, International Journal of Management Economics and Business, Vol.9, No.20, pp.37-55.

- Klein, A. (1998), Firm Performance and Board Committee Structure, Journal of Law and Economics, Vol.41, pp.275-303.

- Klein, A. (2002), Audit Committee, Board of Director Characteristics, and Earnings Management, Journal of Accounting and Economics, Vol.33, pp.375-400.

- Kosowski, R., Timmermann, A., Wermers, R. and White, H. (2006), Can Mutual Fund Stars Really Pick Stocks? New Evidence from a Bootstrap Analysis, Journal of Finance, Vol.61, No.6, pp.2551-2595.

- $\quad$ Litov, L. P., Sepe, S. M. and Whitehead, C. K. (2014), Lawyers and Fools: Lawyerdirectors in Public Corporations, Cornell Law Faculty Publications, Paper 673.

- Nuhoglu, I. and Armagan, O. (2013), The Status of Audit Committees: A Comparative Study of U.S.A, E.U., and Turkey, MODAV Journal, Vol.15, No.1, pp.67-86.

- Sevim, S. and Eliuz, A. (2007), ). Denetim Komitelerinin İç Denetimin Etkinliği Üzerindeki Rolleri ve iMKB'de Bir Araştırma, The Journal of Accounting and Finance, Vol.36, pp.60-70.

- Shivdasani, A. and Yermack, D. (1999), CEO Involvement in the Selection of New Board Members: An Empirical Analysis, Journal of Finance, Vol.54, No.5, pp.18291853.

- Tahaoglu, C. and Guner, Z. N. (2011), An Investigation of Returns to Insider Transactions: Evidence from the Istanbul Stock Exchange, Bogazici Journal, Vol.25, No.1, pp.57-77.

- Tao, N. B. and Hutchhinson, M. (2013), Corporate Governance and Risk Management: The Role of Risk Management and Compensation Committees, Journal of Contemporary Accounting \& Economics, Vol.9, No.1, pp.83-99.

- Unlu, U. (2012), Dort Faktorlu Varlık Fiyatlama Modelinin IMKB'de Test Edilmesi, Iktisat Isletme ve Finans, Business and Finance, Vol.27, No.313, pp.57-83. 
- Uzun, H., Szewczyk, S. H. and Varma, R. (2004), Board Composition and Corporate Fraud, Financial Analysts Journal, Vol.60, No.3, pp.33-43.

- Xie, B., Davidson, N. D. and DaDalt, P. J. (2003), Earnings Management and Corporate Governance: The Role of the Board and the Audit Committee, Journal of Corporate Finance, Vol.9, No.3, pp.295-316. 
Appendix 1: Robustness Tests I - Committee Establishment and Member Appointment

PANEL A: 3 Factor Model with XTUM as Market Return

\begin{tabular}{lrrrrr}
\hline & $\begin{array}{r}\text { CAAR } \\
\text { (-1,+1) }\end{array}$ & $\begin{array}{r}\text { Number } \\
\text { of } \\
\text { Events }\end{array}$ & $\begin{array}{r}\text { Cross- } \\
\text { Sect. t- } \\
\text { test }\end{array}$ & $\begin{array}{r}\text { BMP } \\
\text { t-test }\end{array}$ & $\begin{array}{r}\text { Sign } \\
\text { Test }\end{array}$ \\
\cline { 2 - 6 } Risk Committee Establishment & $0.893 \%$ & 16 & 1.24 & 0.83 & 0.50 \\
Governance Committee Establishment & $0.047 \%$ & 111 & 0.11 & 0.78 & -1.04 \\
\hline PCG Regulation - (Audit C.) & $0.618 \%$ & 43 & 1.06 & 0.89 & 0.15 \\
First Time Comm. Establish. - (Audit C.) & $-0.401 \%$ & 40 & -1.29 & -1.40 & -1.89 \\
Previous One Left - (Audit C.) & $0.998 \%$ & 30 & 1.89 & 1.30 & 1.09 \\
\hline PCG Regulation - (Risk C.) & $0.061 \%$ & 42 & 0.11 & -0.56 & -0.61 \\
First Time Comm. Establish. - (Risk C.) & $-1.083 \%$ & 8 & -0.94 & 0.01 & 0.00 \\
Previous One Left - (Risk C.) & $0.079 \%$ & 265 & 0.26 & 1.43 & -1.16 \\
\hline PCG Regulation - (Govern C.) & $0.097 \%$ & 27 & 0.18 & 0.09 & 0.96 \\
First Time Comm. Establish. - (Govern & $-0.270 \%$ & 22 & -0.76 & -0.35 & -0.42 \\
C.) & & & & & \\
Previous One Left - (Govern C.) & $0.444 \%$ & 98 & 1.18 & 0.74 & -0.40 \\
\hline
\end{tabular}

PANEL B: 4 Factor Model with X100 as Market Return

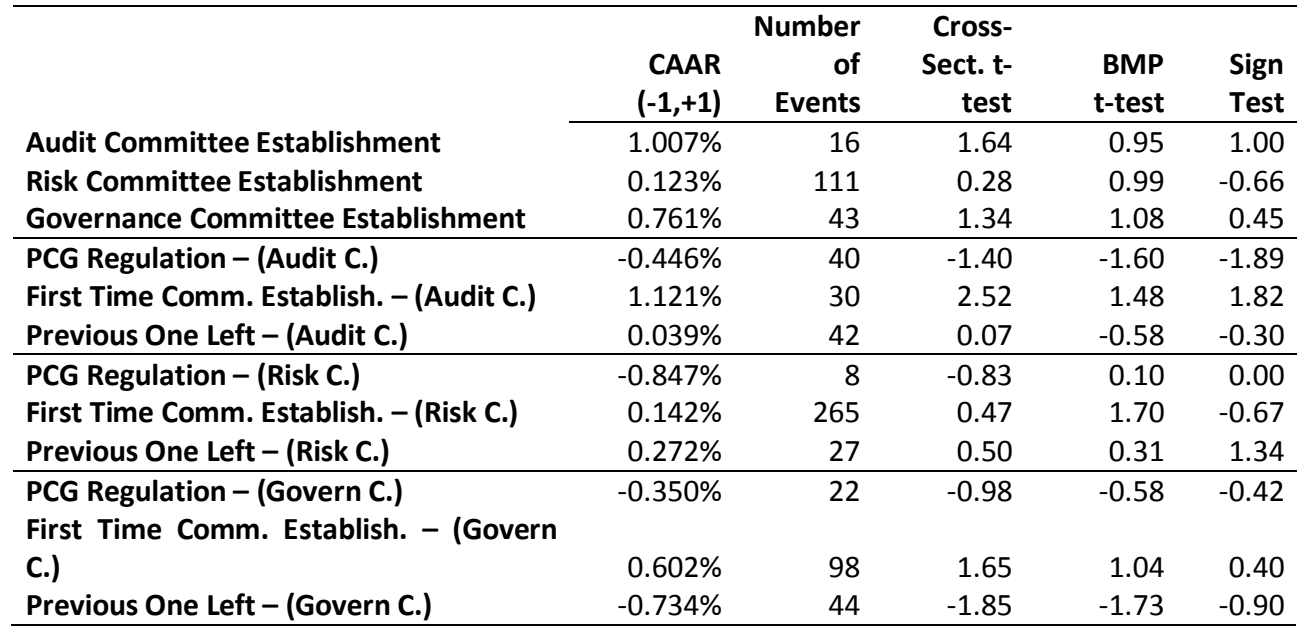

Panel A presents findings based on the 3 Factor Model as the market return and the return of the XTUM index as the market return. Panel B presents findings based on the 4 Factor Model as the market model and the return of the X100 index as the market return. The sample includes all the firms traded at the BIST. 
Appendix 2: Robustness Tests II: Committee Member Expertise

PANEL A: 3 Factor Model with XTUM as Market Return

\begin{tabular}{|c|c|c|c|c|c|}
\hline & & Number & Cross- & & \\
\hline & $\begin{array}{r}\text { CAAR } \\
(-1,+1) \\
\end{array}$ & $\begin{array}{r}\text { of } \\
\text { Events }\end{array}$ & $\begin{array}{r}\text { Sect. } t- \\
\text { test }\end{array}$ & $\begin{array}{l}\text { BMP } \\
\text { t-test }\end{array}$ & $\begin{array}{l}\text { Sign } \\
\text { Test }\end{array}$ \\
\hline Expert Appointment - (Audit C.) & $* * 0.550 \%$ & 62 & 1.38 & 1.00 & 1.52 \\
\hline Expert Departure - (Audit C.) & $0.428 \%$ & 28 & 0.59 & 0.22 & 1.13 \\
\hline Non-Expert Appointment - (Audit C.) & $-0.622 \%$ & 44 & -1.33 & -2.19 & -2.71 \\
\hline Non-Expert Departure - (Audit C.) & $-1.789 \%$ & 14 & -1.37 & -1.41 & -0.53 \\
\hline Expert Appointment - (Risk C.) & $0.010 \%$ & 166 & 0.03 & 1.00 & -0.31 \\
\hline Expert Departure - (Risk C.) & $0.178 \%$ & 27 & 0.40 & 0.12 & 1.34 \\
\hline Non-Expert Appointment - (Risk C.) & $0.219 \%$ & 108 & 0.37 & 1.2 & -0.19 \\
\hline Non-Expert Departure - (Risk C.) & $-0.387 \%$ & 9 & -0.62 & 0.13 & -0.33 \\
\hline Expert Appointment - (Govern. C.) & $-0.151 \%$ & 76 & -0.38 & -0.21 & -0.22 \\
\hline Expert Departure - (Govern. C.) & $-0.290 \%$ & 30 & -0.63 & -0.48 & 0.73 \\
\hline Non-Expert Appointment - (Govern. C.) & $0.129 \%$ & 86 & 0.35 & -0.26 & -0.86 \\
\hline Non-Expert Departure - (Govern. C.) & $-1.639 \%$ & 22 & -1.80 & -1.32 & -0.85 \\
\hline
\end{tabular}

PANEL B: 4 Factor Model with X100 as Market Return

\begin{tabular}{lrrrrr}
\hline & $\begin{array}{r}\text { CAAR } \\
(-\mathbf{1}+\mathbf{1})\end{array}$ & $\begin{array}{r}\text { Number } \\
\text { of } \\
\text { Events }\end{array}$ & $\begin{array}{r}\text { Cross- } \\
\text { Sect. t- } \\
\text { test }\end{array}$ & $\begin{array}{r}\text { BMP } \\
\text { t-test }\end{array}$ & $\begin{array}{r}\text { Sign } \\
\text { Test }\end{array}$ \\
\cline { 2 - 6 } Expert Appointment - (Audit C.) & $* * 0.568 \%$ & 62 & 1.49 & 1.04 & 2.03 \\
Expert Departure - (Audit C.) & $0.324 \%$ & 28 & 0.47 & 0.15 & 1.13 \\
Non-Expert Appointment - (Audit C.) & $-0.659 \%$ & 44 & -1.49 & -2.35 & -2.71 \\
Non-Expert Departure - (Audit C.) & $-1.530 \%$ & 14 & -1.21 & -1.24 & -0.53 \\
\hline Expert Appointment - (Risk C.) & $0.135 \%$ & 166 & 0.45 & 1.43 & 0.31 \\
Expert Departure - (Risk C.) & $0.238 \%$ & 27 & 0.51 & 0.23 & 0.96 \\
Non-Expert Appointment - (Risk C.) & $0.256 \%$ & 108 & 0.44 & 1.30 & 0.00 \\
Non-Expert Departure - (Risk C.) & $-0.149 \%$ & 9 & -0.23 & 0.29 & -0.33 \\
\hline Expert Appointment - (Govern. C.) & $-0.081 \%$ & 76 & -0.21 & -0.09 & 0.00 \\
Expert Departure - (Govern. C.) & $-0.199 \%$ & 30 & -0.44 & -0.33 & -0.36 \\
Non-Expert Appointment - (Govern. C.) & $0.202 \%$ & 86 & 0.56 & -0.09 & -0.43 \\
Non-Expert Departure - (Govern. C.) & $-1.493 \%$ & 22 & -1.68 & -1.21 & -0.85 \\
\hline
\end{tabular}

Panel A presents findings based on the 3 Factor Model as the market return and the return of the XTUM index as the market return. Panel B presents findings based on the 4 Factor Model as the market model and the return of the X100 index as the market return. The sample includes all the firms traded at the BIST. The CAARs are compared for director subgroups. The significance levels based on Wilcoxon signed-rank tests are reported. *, $* *$, and $* * *$ present significance at $10 \%, 5 \%$, and $1 \%$ levels. 